\title{
An Analysis of Real-Estate Risk Using the Present Value Model
}

\author{
Crocker H. Liu \\ New York University \\ Jianping Mei \\ New York University
}

\begin{abstract}
The current study uses a present value model that allows for a time-varying expected discount rate in conjunction with a VAR process to decompose real-estate risk. The study finds that the variance of unexpected returns accounts for most of the total risk with cash-flow risk accounting for twice as much of the unexplained real-estate risk although discount rate risk is also an important factor. This dominance of cash-flow risk is found to result in a weaker mean reversion process for real estate relative to stocks. Another finding is that real estate investors tend to become apprehensive about the future when news on future cash flow is good, and thus they demand higher expected future returns.
\end{abstract}

Key words: Real-Estate Risk, VAR model, Risk Decomposition, REIT

The analysis of real-estate risk has typically focused on either the understatement of risk arising from the smoothed nature of appraisal-based returns or the systematic components of risk from an arbitrage pricing (APT) perspective. ${ }^{1}$ In contrast, little research exists on partitioning the volatility of total return using a present value framework. The purpose of the current study, therefore, is to examine real-estate risk by first decomposing total risk into expected and unexpected movements in asset prices. The unexpected variation in total risk is further decomposed into two risk components-changes in rational expectations of future real dividend growth and future expected returns, which we will hereafter refer to as cash-flow risk and discount-rate risk respectively. To decompose the variance, the present value model of (Campbell 1987, 1991), which allows the expected discount rate to vary through time, is used in conjunction with a vector autoregressive (VAR) process.

Focusing on risk using a present value model framework offers several distinct advantages not available with an APT structure. Most important, the present value model is geared to how real estate is typically valued since the traditional analysis of real estate involves analyzing the cash flows of a property using a constant discount rate to obtain a value. By modifying the present value to allow the expected discount rate to vary over time, we can directly assess how the value of the property fluctuates over time by examining variations in the cash flows, variations in the expected discount rate, or a combination of the two. This intertemporal linkage of cash flow to value is more tenuous in applying the APT framework to real estate because it is difficult to assess how these cash flows will change over time and in turn how

\footnotetext{
${ }^{1}$ Studies that have looked at the understatement of real-estate risk arising from the smoothed nature of appraisal based returns include Ross and Zisler (1987) and Geltner (1989). On the other hand, Titman and Warga (1986) and Chan, Hendershott, and Sanders (1990) have examined the risk-adjusted performance of equity REITs using an arbitrage pricing framework.
} 
value will vary on an intertemporal basis given that the different macroeconomic factors corresponding to systematic risks are not directly related to the

cash flows of a property. Consequently, the modified present value approach used here represents a new perspective on linking the traditional fundamental analysis in real estate to the asset pricing literature.

The study builds on the earlier work of Liu and Mei (1991) who examine the predictability of expected returns on equity REITs and their co-movements with other assets. The current study focuses on movements in unexpected real returns on equity REITs compared to that for other assets using a VAR approach to decompose the variance of unexpected asset returns. The importance of each component of unexplained risk does not only depend on the ability to forecast asset returns but also depends on its intertemporal characteristics associated with the forecasted component of returns. Hence, this study complements the study of Liu and Mei (1991).

Another relevant study is the study by Geltner (1990), which uses a discounted cash flow model of property value. Although Geltner (1990) explores real-estate risk in terms of cashflow risk, his model does not allow the discount rate to vary nor are returns decomposed into expected and unexpected components. This suggests that all movements in real estate prices must only be due to news about expected future cash flows if one rules out "rational bubbles." Thus, only one interpretation of real estate market movements is permitted, and therefore his study represents a special case of the current study. Geltner (1990) provides no empirical verification of his theoretical model.

When we first decompose the variance of total real returns for each asset into the variance associated with contemporaneous expected returns and the variance of unexpected returns, we find that fluctuations in expected contemporaneous returns account for only a small portion of the variation in total returns. When we further decompose the variance of unexpected returns for each asset into cashflow risk, discount-rate risk, and the covariance between these two risks, we find that the relative influence of each of these components differs for each asset class. For equity REITs, cash-flow risk accounts for the major portion of unexplained risk. Discount-risk accounts for most of the variation in small stock returns while cash-flow risk, discount-rate risk, and covariance risk are of equal importance in accounting for unexplained movements in value-weighted stocks. Consequently, even though Liu and Mei (1991) and Gyourko and Keim (1991) find that equity REITs behave like small cap stocks with respect to movements in expected returns, this study suggests that the relative influence of each of the three risk components differs for EREITs and small stocks with respect to the variance of their unexpected asset returns. Although cash-flow risk is the dominant risk characteristic for equity REITs, we find that discount-rate risk and covariance risk are also important in unexpected real-estate risk components. The study also finds that mean reversion is much weaker for equity REITs than it is for either value-weighted or small stocks. This implies that a relatively longer holding period is required for real estate if a contrarian investment strategy is followed.

The remainder of the paper is organized as follows. The next section discusses the framework used to view the relationship between unexpected returns and movements in expected returns. The section also 
describes the VAR approach used to decompose the variance of stock returns. Section 2 describes our data set. Our empirical results, including the extent to which the unexpected variation of equity REIT returns is associated with different types of risks, are reported in section 3 . Section 4 concludes the study.

\section{The Basic Framework and Estimation Process}

\subsection{The Relationship Between Expected Returns and Unexpected Returns}

The log-linear dividend-ratio model of Campbell (1991) and Campbell and Shiller (1988a) is used to characterize the relationship between the unexpected real asset return in the next period $(t+1)$ and changes in rational expectations of future dividend growth and future asset returns. Thus, the model allows both expected future cash flows and expected returns (discount rates) to influence asset prices. More formally, the fundamental equation used in this paper is

$$
\boldsymbol{h}_{t+1}-E_{t} \boldsymbol{h}_{t+1}=\left(E_{t+1}-E_{t}\right) \sum_{j=0}^{\infty} \rho^{j} \Delta d_{t+1+j}-\left(E_{t+1}-E_{t}\right) \sum_{j=0}^{\infty} \rho^{j} h_{t+1+j}
$$

where Et is the expectation formed at the end of period $\boldsymbol{t}, \boldsymbol{h}_{\boldsymbol{t}+\mathbf{1}}$ represents the log of the real return on an asset held from the end of period $t$ to the end of period $t+1, \boldsymbol{d}_{t+1}$ is the log of the real dividend paid during period $t+1, \Delta$ denotes a one-period backward difference, and $\left(\boldsymbol{E}_{\boldsymbol{t}+\mathbf{1}}-\boldsymbol{E}_{\boldsymbol{t}}\right)$ represents a revision in expectations given that new information arrived at time $t+1$. The parameter $\boldsymbol{\rho}$ is a constant and is constrained to be smaller than 1. A more detailed derivation of the model is given in the appendix. The main point of equation 1 is that if the unexpected return on an asset is negative given that expectations are internally consistent, then it follows that either the expected future growth in cash flows (dividends) must decrease, the expected future returns (discount rate) on an asset must increase, or both. The intuition for this result is that if we consider an asset with fixed dividends, say real estate leased on a long-term basis with stationary fixed rents whose price falls, the cap rate on the property will increase, which in turn will increase the property's return unless a further capital loss occurs. However, capital losses on real estate cannot continue forever, so at some point the property must experience higher returns.

For our study, we will use a more compact version of equation 1 written as follows:

$$
v_{h, t+1}=\eta_{d, t+1}-\eta_{h, t+1}
$$

where $\boldsymbol{v}_{\boldsymbol{h}, \boldsymbol{t + 1}}$ is the unexpected component of the stock return $\boldsymbol{h}_{\boldsymbol{t}+\mathbf{1}}, \boldsymbol{\eta}_{\boldsymbol{d}, \boldsymbol{t + 1}}$ represents news about cash flows, and $\boldsymbol{\eta}_{\boldsymbol{h}, \boldsymbol{t}+\mathbf{1}}$ represents news about future returns (discount rate).

\subsection{The Estimation Procedure}

We model six economic state variables including the asset returns on three asset portfolios (valueweighted stocks, small stocks and equity REITs), the dividend yield, the yield on one-month Treasury bills, and the cap rate on real estate, according to a K-order VAR process given that Campbell (1988), 
Campbell and Ammer (1990), Campbell and Mei (1991), Campbell and Shiller (1988), and others have found that the VAR process provides a useful framework to summarize data. The VAR approach assumes that the variables in the process are stationary time-series and can thus be modelled using an autoregressive (AR) model. ${ }^{2}$ The fact that lagged state variables are present in an autoregressive process is not necessarily contradictory to market efficiency if the risk premiums paid on assets vary over time due to changing economic conditions. If this is the case, then the lagged variables in the VAR process serves as a proxy for the economic state variables that drive the risk premium, and this also provides us with some clue as to what relevant variables to include in the VAR model of asset pricing dynamics. As in previous studies, the dividend yield on an equally weighted portfolio of all stocks on CRSP, which is measured as the total dividends paid over the previous year relative to the current stock price, is included in the VAR process because it captures information on any changes that may occur in future expected returns [c.f. Campbell and Shiller (1988a, b), Campbell and Mei (1991), Fama and French (1988b), Liu and Mei (1991), and Mei and Saunders (1991)]. ${ }^{3}$ We also include the T-bill variable, which describes the short-term interest rate, and the cap rate, which captures information on expected future cash flows and required returns in the underlying real estate market. ${ }^{4}$ We include the cap rate as a forecasting variable given the finding in Liu and Mei (1991) that movements in the cap rate do not necessarily contain the same information as fluctuations in the dividend yield on the stock market. ${ }^{5}$

To be more specific about the VAR process, the approach involves defining a vector $\boldsymbol{z}_{\boldsymbol{t}+\mathbf{1}}$ that has $\mathrm{k}$ elements, the first of which are the real asset returns $\boldsymbol{h}_{\boldsymbol{t}+\mathbf{1}}$ in consideration (e.g., REITs). Additional elements in this vector are other variables that are known to the market at the end of period $t+1$.

\footnotetext{
${ }^{2}$ To test whether the variables in the process are stationary, we performed three versions of the Dickey-Fuller test on each variable focusing especially on the cap rate variable given one reviewer's concern that the cap rate data might be strongly persistent, particularly over monthly intervals. The three versions of the Dickey-Fuller test include a standard test, the standard test with a constant, and a standard test with a constant and a time trend [see (Harvey, 1990)]. The Dickey-Fuller test showed that the cap rate variable was stationary over the time in our study.

${ }^{3}$ To see this, consider the ex ante version of equation $\mathrm{A} 2$ in the appendix.

${ }^{4}$ The cap rate is defined as the ratio of net stabilized earnings to the transaction price (or market value) of a property. Net stabilized income is calculated under the assumption that the percent occupancy in the building is equal to or greater than the occupancy rate for comparable existing buildings in the market in which a property trades. In other words, the vacancy rate has stabilized relative to the vacancy rate that exists during the leasing up period of a new building. Net stabilized income is computed on a monthly or quarterly basis and then annualized. The transaction price is the gross price paid for the property. In some cases, the appraisal value is used in lieu of the transaction price by those who report cap rates. The cap rate used in this paper is the average of the cap rates for individual properties for which this information is made available to the ACLI. Alternatively, the cap rate can be thought of as the earnings-price ratio on direct real estate investment.

${ }^{5}$ In contrast to Liu and Mei (1991), we do not use a January dummy and the spread between the yields on longterm AAA corporate bonds and the 1-month Treasury bill as forecasting variables. The January dummy is omitted given the nature of the $\backslash A R$ process while the spread variable is not used because it was not statistically significant in either Liu and Mei (1991) or in this study for value-weighted stocks, small stocks, and equity REITs. In addition to this, the parameter estimates appear to be invariant to the inclusion or exclusion of the spread variable. The parameter estimates also appear to be robust to the inclusion or exclusion of the dividend yield on an equally weighted portfolio consisting of all equity REITs on the CRSP tapes. The results of the study, which include the spread variable and the equally weighted dividend yield on equity REITs are available from the authors on request.
} 
Although we initially model asset returns under the assumption that the vector $\mathbf{z}_{\boldsymbol{t}+\mathbf{1}}$ follows a first-order VAR process shown in equation 3 below, we later relax this assumption:

$$
z_{t+1}=A z_{t}+w_{t+1}
$$

Higher-order VAR models that we employ are stacked into this VAR(1) model in the same manner as discussed in Campbell and Shiller (1988a). ${ }^{6}$ In equation 3, the matrix $\boldsymbol{A}$ is known as the companion matrix of the VAR.

In addition to the vector $\mathbf{z}_{t+1}$, we also define a $\boldsymbol{k}$-element vector $\boldsymbol{e}_{1}$; whose elements are all equal to zero except the first element, which is equal to 1 . The vector $\boldsymbol{e}_{1}$ is used to separate out real-asset returns $\boldsymbol{h}_{t+1}$ from the vector $\boldsymbol{z}_{t+1}$ (e.g., $\boldsymbol{h}_{t+1}=\boldsymbol{e}_{1}^{\prime} \boldsymbol{z}_{t+1}$ ) and to extract the unexpected component of real asset returns $\boldsymbol{v}_{h, t+1}=h_{t+1}-\boldsymbol{E}_{t} \boldsymbol{h}_{t+1}=\boldsymbol{e}_{1}^{\prime} \boldsymbol{w}_{t+1}$ from the residual vector $\left(\boldsymbol{w}_{t+1}\right)$ of the VAR process. The $\operatorname{VAR}(1)$ approach produces intertemporal predictions of future expected returns:

$$
E_{t} h_{t+1+j}=e_{1}^{\prime} A^{j+1} z_{t}
$$

From equation 4, it follows that news about future returns or discount rates (the present value of the revisions in forecasted returns) can be defined as

$$
\begin{gathered}
\eta_{h, t+1} \equiv\left(E_{t+1}-E_{t}\right) \sum_{j=1}^{\infty} \rho^{j} h_{t+1+j}=e_{1}^{\prime} \sum_{j=1}^{\infty} \rho^{j} A^{j} w_{t+1}=e_{1}^{\prime} \rho A(I-\rho A)^{-1} w_{t+1} \\
=\lambda^{\prime} w_{t+1}
\end{gathered}
$$

where $\lambda^{\prime}=\boldsymbol{e}_{\mathbf{1}}^{\prime} \boldsymbol{\rho} \boldsymbol{A}(\boldsymbol{I}-\boldsymbol{\rho} \boldsymbol{A})^{-\mathbf{1}}$ is a nonlinear function of the VAR coefficients. In addition to this, given that the first element of $\boldsymbol{w}_{\boldsymbol{t}+\mathbf{1}}$ is $\boldsymbol{v}_{\boldsymbol{h}, \boldsymbol{t + 1}}=\boldsymbol{e}_{\mathbf{1}}^{\prime} \boldsymbol{w}_{\boldsymbol{t}+\mathbf{1}}$. equations 5 and 2 imply that we can calculate cashflow risk if we obtain consistent estimates of $\lambda$ and the residual of the VAR process, $\boldsymbol{w}_{t+1}$ as follows:

$$
\boldsymbol{\eta}_{\boldsymbol{d}, t+1}=\left(\boldsymbol{e}_{1}^{\prime}+\lambda^{\prime}\right) \boldsymbol{w}_{t+1}
$$

Equation 6 is important. It implies that we do not need to observe cash flows to calculate $\boldsymbol{\eta}_{\boldsymbol{d}}$. They can be calculated from estimates of the VAR process. We will use the expressions in equations 5 and 6 to decompose the variance of unexpected asset returns $\left(\boldsymbol{v}_{\boldsymbol{h}, \boldsymbol{t}+\mathbf{1}}\right)$ into the cash-flow risk $\left(\boldsymbol{\eta}_{\boldsymbol{d}, \boldsymbol{t}+\mathbf{1}}\right)$, discountrate risk $\left(\boldsymbol{\eta}_{\boldsymbol{h}, \boldsymbol{t}+\mathbf{1}}\right)$ and a covariance term.

In addition to decomposing the variance of unexpected returns, we utilize a variance ratio test to ascertain whether real estate returns display a similar mean-reverting behavior to returns for value-

\footnotetext{
${ }^{6}$ It is fairly easy to extend the results from a first-order VAR to a K-order VAR because a K-order VAR can easily be rewritten in a first-order matrix form as (3). For example, assuming that $\boldsymbol{z}_{\boldsymbol{t}+\mathbf{1}}=\boldsymbol{A} \boldsymbol{z}_{\boldsymbol{t}}+\boldsymbol{B} \boldsymbol{z}_{\boldsymbol{t}-\boldsymbol{j}}+\boldsymbol{w}_{\boldsymbol{t}+\mathbf{1}}$, by redefining $\boldsymbol{z}_{t}^{*}=\left\{\boldsymbol{z}_{t}, \boldsymbol{z}_{t-1}\right\}^{\prime}$ and $\boldsymbol{w}_{t}^{*}=\left\{\boldsymbol{w}_{\boldsymbol{t}}, \mathbf{0}\right\}^{\prime}$ and $\boldsymbol{A}^{\prime}=\left[\begin{array}{cc}\boldsymbol{A} & \boldsymbol{B} \\ \boldsymbol{t} & \mathbf{0}\end{array}\right]$, we have $\boldsymbol{z}_{\boldsymbol{t}+\mathbf{1}}^{*}=\boldsymbol{A}^{\prime \mathbf{z}_{\boldsymbol{t}}^{*}}+\boldsymbol{w}_{\boldsymbol{t}+\mathbf{1}}^{*}$. Thus, all of the results which we derive for $\boldsymbol{z}_{\boldsymbol{t}+\mathbf{1}}$ also applies to $\boldsymbol{z}_{\boldsymbol{t}+\mathbf{1}}^{*}$.
} 
weighted and small cap stocks. ${ }^{7}$ The variance ratio statistic $\mathrm{V}(\mathrm{K})$, which is defined as the ratio of the variance of $\mathrm{K}$-period returns to the variance of one-period returns, divided by $\mathrm{K}$, can be calculated directly from the autocorrelations of one-period returns by using the fact that

$$
V(K)=1+2 \sum_{j=1}^{K-1}\left(1-\frac{j}{K}\right) \operatorname{Corr}\left(h_{t}, h_{t-j}\right)
$$

The variance ratio equals 1 for white noise returns (i.e., there is no serial correlation in the return series so $\operatorname{Cor} \boldsymbol{r}\left(\boldsymbol{h}_{\boldsymbol{t}}, \boldsymbol{h}_{t-j}\right)=\mathbf{0}$; it exceeds 1 when returns are mostly positively autocorrelated, and it is below 1 when negative autocorrelations dominate.

The Generalized Method of Moments of Hansen (1982) is used to jointly estimate the VAR coefficients and the elements of the variance-covariance matrix of VAR innovations. This estimation procedure allows for conditional heteroskedasticity and possible serial correlation in the error terms of the VAR process. ${ }^{8}$ To calculate the standard errors associated with the estimation error for any statistic, we first let $\boldsymbol{\gamma}$ and $\boldsymbol{V}$ represent the entire set of parameters and the variance-covariance matrix respectively. Next, we write any statistic, such as the covariance between news about future expected returns and discount rates, as a nonlinear function $f(\gamma)$ of the parameter vector $\gamma$. The standard error for the statistic is then estimated as $\sqrt{\left[\mathbf{f}_{\boldsymbol{\gamma}}(\boldsymbol{\gamma})^{\prime} \mathbf{V} \mathbf{f}_{\boldsymbol{\gamma}}(\boldsymbol{\gamma})\right]} \cdot{ }^{9}$

\section{Description of the Data}

Stock prices and dividends are taken from the Center for Research on Security Prices (CRSP) monthly stock tape. We study a value-weighted stock index comprised of all New York Stock Exchange (NYSE) and American Stock Exchange (AMEX) stocks. This value-weighted stock index is biased towards stocks with large market capitalizations. To adjust for this bias, we also include a small cap stock index in our study. Both the value-weighted stock index and the small cap stock index are obtained from the Ibbotson and Associates Stocks, Bonds, Bills, and Inflation series in CRSP. We also construct an equally weighted equity REIT return series using all equity REITs in CRSP from January 1971 to December 1989 to avoid the problem of survivorship bias. Another advantage to using an EREIT portfolio which consists of between 25 to 35 equity REITs on average over most of the study period) is that we avoid the smoothing issue

${ }^{7}$ Campbell (1990), Cochrane (1988), Lo and MacKinlay (1988), and Poterba and Summers (1988), have all used the variance ratio test to document the mean reverting behavior of stock returns. Kandel and Stambaugh (1988) also report a number of calculations of this type. However, some controversy exists on the presence of mean-reversion. The controversy centers around whether the evidence on mean-reversion arises from a slowly reverting omponent of stock prices or from the weak power associated with the variance ratio test since this statistic is based on asymptotic theory but is applied to finite samples. For example, Richardson and Stock (1989) argue that large-sample approximations to sampling distributions perform poorly in practice because there is not much independent information in a long time series of multi-year returns due to the small number of nonoverlapping observations.

${ }^{8} \mathrm{GMM}$ approach used in the paper is designed to alleviate some of the measurement error problems in the data. Parameter estimates obtained from using GMM will be consistent, as long as the measurement errors are uncorrelated with lagged instrumental variables.

${ }^{9}$ For example, see Chow (1982), Campbell (1991), Campbell and Mei (1991) and Campbell and Shiller (1988a). 
associated with using appraisal-based returns even though we recognize that the volatility of real-estate returns might be overstated due to the closed-end nature of REITs. A REIT is deemed to be an equity REIT if it is listed as such in at least two of the following three sources: (1) REIT Sourcebook published by the National Association of Real Estate Investment Trusts, Inc., (2) The Realty Stock Review published by Audit Investments, and (3) Moody's Bank and Finance Manual, Volume 2.

The yield on the one-month Treaury bill and the dividend yields on the equally weighted market portfolio are obtained from Federal Reserve Bulletin and Ibbotson and Associates (1989). Monthly cap rates on real estate are taken from the American Council of Life Insurance publication Investment Bulletin: Mortgage Commitments on Multifamily and Nonresidential Properties Reported by 20 Life Insurance Companies. ${ }^{10}$

\section{Empirical Results}

Table 1 provides summary statistics on real returns for our portfolios of value-weighted stocks, equity REITs, and small cap stocks as well as for our forecasting variables. Table 1 reveals that although equity REITs resemble large cap stocks (value-weighted stocks) with respect to their volatility, EREITs tend to behave more like small cap stocks from the perspective of mean returns and correlations. Table 1 also reveals that the returns for equity REITs and small cap stocks have a higher positive, first-order serial correlation relative to large cap stocks, which might suggest that the return on these assets are more predictable. These findings are consistent with the evidence in Gyourko and Keim (1991) and Liu and Mei (1991).

Table 2. Basic VAR results for real stock returns using generalized method of moments.

One lag, monthly: Period 1971.01 to 1989.03 (T statistics in parentheses).

\begin{tabular}{|c|c|c|c|c|c|c|c|c|c|}
\hline $\begin{array}{c}\text { Dependent } \\
\text { Varjable }\end{array}$ & VWStk $_{t}$ & EREITs, & SmStk, & DivYld, & $\mathrm{CapR}_{\mathrm{t}}$ & TBill, & $\mathbf{R}^{2}$ & P-Value & DW \\
\hline VWStk $_{t+1}$ & $\begin{array}{r}0.080 \\
(0.56)\end{array}$ & $\begin{array}{r}0.157 \\
(1.32)\end{array}$ & $\begin{array}{l}-0.108 \\
(-0.90)\end{array}$ & $\begin{array}{r}1.149 \\
(1.48)\end{array}$ & $\begin{array}{l}0.662 \\
(1.65)\end{array}$ & $\begin{array}{l}-0.519 \\
(-3.21)\end{array}$ & .073 & 0.01 & 1.95 \\
\hline EREITs $_{\mathbf{t + 1}}$ & $\begin{array}{l}0.217 \\
(1.43)\end{array}$ & $\begin{array}{r}0.010 \\
(0.07)\end{array}$ & $\begin{array}{r}-0.052 \\
(-0.49)\end{array}$ & $\begin{array}{r}1.030 \\
(0.97)\end{array}$ & $\begin{array}{l}0.966 \\
(2.27)\end{array}$ & $\begin{array}{r}-0.509 \\
(-2.56)\end{array}$ & .088 & $0 . \infty 0$ & 1.95 \\
\hline StnStk $_{t+1}$ & $\begin{array}{r}0.211 \\
(1.15)\end{array}$ & $\begin{array}{r}0.049 \\
(0.29)\end{array}$ & $\begin{array}{r}-0.043 \\
(-0.27)\end{array}$ & $\begin{array}{r}2.538 \\
(2.41)\end{array}$ & $\begin{array}{r}0.905 \\
(1.63)\end{array}$ & $\begin{array}{r}-0.752 \\
(-3.12)\end{array}$ & .109 & 0.00 & 1.95 \\
\hline $\operatorname{DivYld}_{t+1}$ & $\begin{array}{l}-0.010 \\
(-1.30)\end{array}$ & $\begin{array}{l}-0.001 \\
(-0.17)\end{array}$ & $\begin{array}{c}0.006 \\
(0.94)\end{array}$ & $\begin{array}{r}0.906 \\
(16.14)\end{array}$ & $\begin{array}{r}-0.047 \\
(-2.31)\end{array}$ & $\begin{array}{r}0.035 \\
(3.64)\end{array}$ & .904 & 0.00 & 2.00 \\
\hline CapR $_{t+1}$ & $\begin{array}{c}-0.001 \\
(-0.07)\end{array}$ & $\begin{array}{c}-0.004 \\
(-0.61)\end{array}$ & $\begin{array}{r}0.003 \\
(0.40)\end{array}$ & $\begin{array}{r}0.062 \\
(1.81)\end{array}$ & $\begin{array}{r}0.868 \\
(22.87)\end{array}$ & $\begin{array}{r}0.040 \\
(3.42)\end{array}$ & .925 & 0.00 & 2.69 \\
\hline TBill $_{t+1}$ & $\begin{array}{r}0.005 \\
(0.17)\end{array}$ & $\begin{array}{r}0.061 \\
(2.09)\end{array}$ & $\begin{array}{l}-0.020 \\
(-0.72)\end{array}$ & $\begin{array}{l}-0.074 \\
(-0.50)\end{array}$ & $\begin{array}{c}0.103 \\
(1.05)\end{array}$ & $\begin{array}{r}0.904 \\
(20.77)\end{array}$ & .851 & 0.00 & 2.11 \\
\hline
\end{tabular}

Notes: The T statistics are corrected for heteroskedasticity. The P-Value refers to the significance level for a test of the hypothesis that all regression coefficients are zero. DW is the Durbin-Watson statistic. The numbers in the preceding table differ from thos in Liu and Mei (1991) since their paper employs excess returns on a nominal basis whereas real returns are used in the current study.

\footnotetext{
${ }^{10}$ Unfortunately, the ACLI does not break down monthly cap rates by type of real estate. This is only done with respect to quarterly cap rates.
} 
The results of regressing the mean adjusted real stock returns on six forecasting variables, the lag of the return of different stock categories in addition to the returns on Treasury bills, the dividend yield on the equally weighted market portfolio, and the cap rate are reported in table 2 for a VAR(1) process. ${ }^{11}$

Although we show that this $\operatorname{VAR}(1)$ process isn't well specified in table 3, we present the results here for simplicity to give the reader some idea of the estimation of the VAR model since our primary concern is the decomposition of the unexplained variation in real returns associated with various stock categories rather than the predictability of returns. The results in table 2 differ slightly from those in Liu and Mei (1991) since the current study uses real returns in lieu of nominal excess returns and also uses the lag of the dependent variables as predictors. The use of lagged dependent variables dampens the impact of some of the other predictor variables such as the dividend yield, which was significant for both valueweighted and small cap stocks in Liu and Mei (1991) but is not significant for value-weighted stocks in this study. Like Liu and Mei (1991) however, the cap rate is a significant forecasting variable with respect to equity REITs and small cap stocks while the T-bill is a significant predictor of returns for all stock categories.

Table 2. Basic VAR results for real stock returns using generalized method of moments. One lag, monthly: Period 1971.01 to 1989.03 (T statistics in parentheses).

\begin{tabular}{|c|c|c|c|c|c|c|c|c|c|}
\hline $\begin{array}{c}\text { Dependent } \\
\text { Variable }\end{array}$ & vWStk $_{t}$ & EREITs, & SmStk, & DiVYld, & CapRt $_{t}$ & TBill, & $\mathbf{R}^{2}$ & P-Value & DW \\
\hline VWStk $_{t+1}$ & $\begin{array}{r}0.080 \\
(0.56)\end{array}$ & $\begin{array}{r}0.157 \\
(1.32)\end{array}$ & $\begin{array}{c}-0.108 \\
(-0.90)\end{array}$ & $\begin{array}{r}1.149 \\
(1.48)\end{array}$ & $\begin{array}{r}0.662 \\
(1.65)\end{array}$ & $\begin{array}{r}-0.519 \\
(-3.21)\end{array}$ & .073 & 0.01 & 1.95 \\
\hline EREITs $_{\mathbf{t + 1}}$ & $\begin{array}{r}0.217 \\
(1.43)\end{array}$ & $\begin{array}{r}0.010 \\
(0.07)\end{array}$ & $\begin{array}{r}-0.052 \\
(-0.49)\end{array}$ & $\begin{array}{r}1.030 \\
(0.97)\end{array}$ & $\begin{array}{r}0.966 \\
(2.27)\end{array}$ & $\begin{array}{l}-0.509 \\
(-2.56)\end{array}$ & .088 & $0 . \infty 0$ & 1.95 \\
\hline StmStk $_{t+1}$ & $\begin{array}{r}0.211 \\
(1.15)\end{array}$ & $\begin{array}{r}0.049 \\
(0.29)\end{array}$ & $\begin{array}{r}-0.043 \\
(-0.27)\end{array}$ & $\begin{array}{r}2.538 \\
(2.41)\end{array}$ & $\begin{array}{r}0.905 \\
(1.63)\end{array}$ & $\begin{array}{r}-0.752 \\
(-3.12)\end{array}$ & .109 & 0.00 & 1.95 \\
\hline $\operatorname{DivYld}_{t+1}$ & $\begin{array}{r}-0.010 \\
(-1.30)\end{array}$ & $\begin{array}{r}-0.001 \\
(-0.17)\end{array}$ & $\begin{array}{r}0.006 \\
(0.94)\end{array}$ & $\begin{array}{r}0.906 \\
(16.14)\end{array}$ & $\begin{array}{r}-0.047 \\
(-2.31)\end{array}$ & $\begin{array}{r}0.035 \\
(3.64)\end{array}$ & .904 & 0.00 & 2.00 \\
\hline $\mathrm{CapR}_{t+1}$ & $\begin{array}{c}-0.001 \\
(-0.07)\end{array}$ & $\begin{array}{r}-0.004 \\
(-0.61)\end{array}$ & $\begin{array}{r}0.003 \\
(0.40)\end{array}$ & $\begin{array}{r}0.062 \\
(1.81)\end{array}$ & $\begin{array}{r}0.868 \\
(22.87)\end{array}$ & $\begin{array}{c}0.040 \\
(3.42)\end{array}$ & .925 & 0.00 & 2.69 \\
\hline TBill $_{t+1}$ & $\begin{array}{r}0.005 \\
(0.17)\end{array}$ & $\begin{array}{r}0.061 \\
(2.09)\end{array}$ & $\begin{array}{r}-0.020 \\
(-0.72)\end{array}$ & $\begin{array}{l}-0.074 \\
(-0.50)\end{array}$ & $\begin{array}{c}0.103 \\
(1.05)\end{array}$ & $\begin{array}{r}0.904 \\
(20.77)\end{array}$ & .851 & 0.00 & 2.11 \\
\hline
\end{tabular}

Notes: The T statistics are corrected for heteroskedasticity. The P-Value refers to the significance level for a test of the hypothesis that all regression coefficients are zero. DW is the Durbin-Watson statistic. The numbers in the preceding table differ from thos in Liu and Mei (1991) since their paper employs excess returns on a nominal basis whereas real returns are used in the current study.

In addition to this, the coefficients associated with the returns on Treasury bills, the dividend yield on the equally weighted market portfolio, and the cap rate for the various assets appear to be relatively

\footnotetext{
${ }^{11}$ In contrast to Liu and Mei (1991), we didn't include bonds because of its distinctive cash flow pattern, which makes it necessary to use a different variation of the present value model from that used in this paper. However, the study does include the impact of changes in interest rates on stocks and real estate. We also drop the term variable used in Liu and Mei (1991) because it was not statistically significant either in Liu and Mei or in this study. Since our parameter estimates were robust to the inclusion or omission of the term variable, we omitted it for reasons of parsimony. The January dummy is also excluded given the nature of the VAR process (e.g., the January effect is implicitly embedded in the model).
} 
invariant to a change in model specification (e.g., the addition of lagged dependent variables and a change in the way returns are measured) when compared to the results of the earlier study by Liu and Mei (1991). This not only suggests that the results of Liu and Mei (1991) are robust, but it also implies that the dividend yield, the T-bill, and the cap rate also influence the predictability of real returns. In fact, as much as $10 \%$ of the variation in returns on equity REITs are predictable. From figure 1 , we can see that the conditional risk premium on these assets using a $\operatorname{VAR}(2)$ model varies over time seeming to peak during a recession and to become relatively small during an economic expansion when these premiums are analyzed with respect to NBER business cycle dates. In other words, investors in real estate securities demand a higher conditional risk premium and therefore higher returns during a recession but are comfortable with lower returns (lower conditional risk premium) when the economy is in an expansion phase.

\begin{tabular}{|c|c|c|c|}
\hline Lag & Equation & F Statistic & P-Value \\
\hline $\mathbf{1}$ & vWStk $_{t+1}$ & 13.18 & .040 \\
\hline 1 & ERETT $_{t+1}$ & 13.96 & .030 \\
\hline 1 & SmStk $k_{t+1}$ & 16.61 & .011 \\
\hline 1 & $\operatorname{DivYla}_{t+1}$ & 1453.46 & .000 \\
\hline 1 & $\mathrm{CapR}_{t+1}$ & 1526.45 & .000 \\
\hline 1 & TBill $_{\mathbf{t}+\mathbf{1}}$ & 691.72 & .000 \\
\hline 2 & VWStk $_{t+1}$ & 11.71 & .068 \\
\hline 2 & EREIT $_{1+l}$ & 11.36 & .078 \\
\hline 2 & SmStk $_{t+1}$ & 9.50 & .147 \\
\hline 2 & DivYld $_{\mathbf{t}+\mathbf{I}}$ & 10.52 & .104 \\
\hline 2 & CapR $_{\mathbf{1}+\mathrm{I}}$ & 23.43 & .001 \\
\hline 2 & TBill $_{1+1}$ & 10.49 & .105 \\
\hline 3 & vwStk $_{t+1}$ & 19.06 & .004 \\
\hline 3 & EREIT $_{1+1}$ & 19.08 & .004 \\
\hline 3 & SmStk $_{t+1}$ & 18.72 & .005 \\
\hline 3 & DivYld $_{t+1}$ & 20.83 & .002 \\
\hline 3 & $\operatorname{CapR}_{t+1}$ & 5.62 & .466 \\
\hline 3 & TBill $_{t+1}$ & 3.26 & .775 \\
\hline 4 & VWStk ${ }_{t+1}$ & 2.96 & .813 \\
\hline 4 & EREIT $_{t+1}$ & 6.32 & .338 \\
\hline 4 & $S m S t k_{t+1}$ & 1.31 & .970 \\
\hline 4 & $\operatorname{DivYld}_{t+1}$ & 3.35 & .762 \\
\hline 4 & CapR $_{1+1}$ & 8.94 & .176 \\
\hline 4 & TBill $_{1+1}$ & 6.02 & .420 \\
\hline
\end{tabular}

In table 3 we report the results of our test on the joint significance of including an additional lag in our VAR model. In other words, we test the incremental effect rather than the total effect of using a VAR(n) model where $\mathrm{n}$ is the number of lagged dependent variables used in the GMM estimation process. The first panel of table 3 indicates that the first lag is definitely necessary since the P-Values are all statistically significant. Moreover, the second panel reveals that the addition of a second lag of the dependent variable adds valuable information because the second lag in the value weighted stocks, equity REITs, and cap rate equations are significant. Panel 3 suggests that a third-order VAR process is 
also necessary. In contrast to this, the last panel indicates that adding a fourth lag to the VAR process does not increase our explanatory power of what accounts for the variation in the variables at time $t$.

We therefore use a $\operatorname{VAR}(2)$ and alternatively use a $\operatorname{VAR}(3)$ process to decompose the variance of real asset returns into the variance of contemporaneous expected asset returns and the variance of unexpected asset returns. The results of this decomposition are reported in table 4 . Table 4 reveals that the variance of contemporaneous expected asset returns accounts for only a minimal portion of the total variation associated with the return on each asset class regardless of whether a $\operatorname{VAR}(2)$ or $\operatorname{VAR}(3)$ process is used. More specifically, the volatility of contemporaneous expected returns on equity REITs account for $9.2 \%-13.3 \%$ of the total real estate risk, while only $5.8 \%-9.2 \%$ of the total risk for valueweighted stocks is due to the variation in expected value-weighted returns. The amount of total risk arising from the variation in contemporaneous expected returns on small stocks is similar to that for equity REITs. In summary, most of the variance of returns for each asset class is associated with the variance of unexpected asset returns.

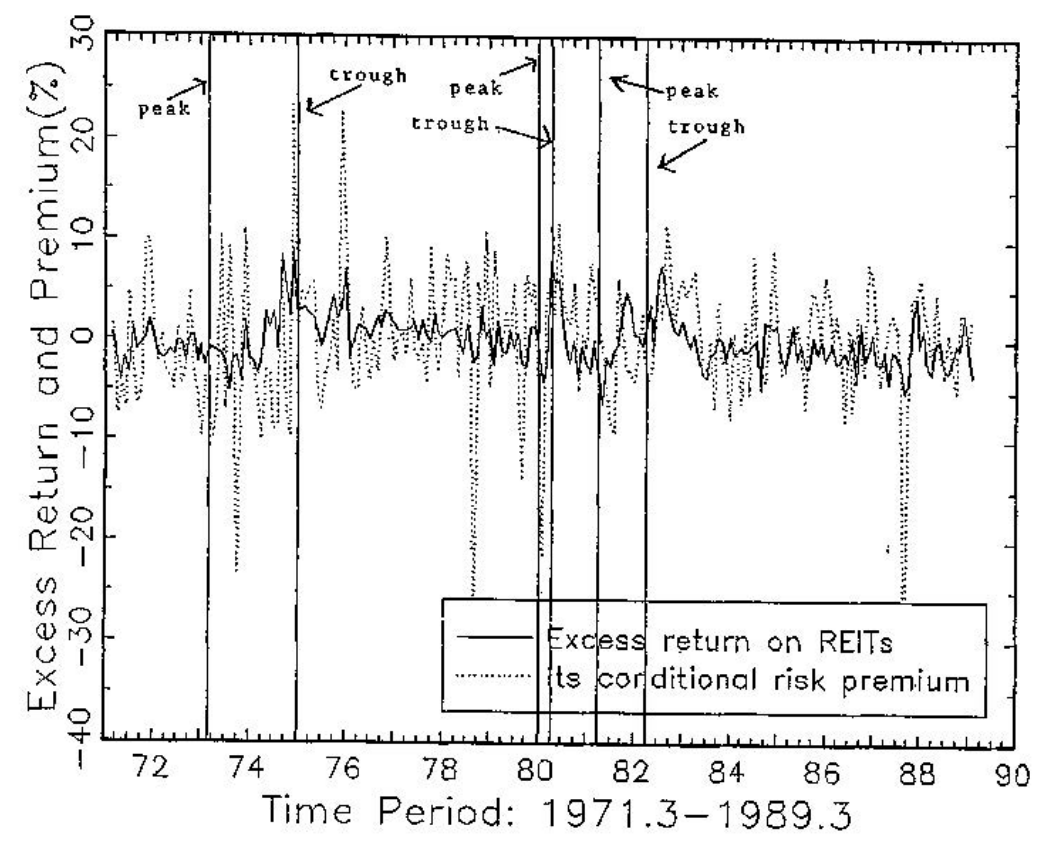

Figure 1. Excess returns on REITs and its conditional-risk premiums. 
Table 4. Variance decomposition of total real asset returns (variance of expected asset returns and variance of unexpected asset returns).

\begin{tabular}{|c|c|c|c|c|c|c|}
\hline $\begin{array}{l}\text { I. VAR(2) Process } \\
\text { Asset Category }\end{array}$ & $R^{2}$ & $\begin{array}{c}\text { Total Variance } \\
\sigma^{2}\end{array}$ & $=$ & $\begin{array}{c}\text { Expected } \\
\sigma_{\mathrm{E}}^{2}\end{array}$ & + & $\begin{array}{c}\text { Unexpected } \\
\sigma_{e}^{2}\end{array}$ \\
\hline Value-Weighted Stocks & .058 & 23.310 & & 1.345 & & 21.965 \\
\hline Equity REITs & .092 & 24,950 & & 2.285 & & 22.665 \\
\hline Stnall Cap Stocks & .090 & 45.482 & & 4.075 & & 41.406 \\
\hline \multicolumn{7}{|l|}{ II. VAR(3) Process } \\
\hline Asset Category & $\mathrm{R}^{2}$ & $\begin{array}{c}\text { Total Variance } \\
\sigma^{2}\end{array}$ & $=$ & $\begin{array}{c}\text { Expected } \\
\sigma_{\mathrm{E}}^{2}\end{array}$ & + & $\begin{array}{c}\text { Unexpected } \\
\sigma_{\epsilon}^{2}\end{array}$ \\
\hline Value-Weighted Stocks & .092 & 23.310 & & 2.154 & & 21.156 \\
\hline Equity REITs & .133 & 24.950 & & 3.318 & & 21.632 \\
\hline Small Cap Stocks & .121 & 45.482 & & 5.503 & & 39.978 \\
\hline
\end{tabular}

Notes: $\sigma^{2}$ is defined as the variance of total real returns for each asset. This variance can be decomposed into two components: $\sigma_{\mathrm{E}}^{2}$, which is defined as the variance of expected asset returns, and $\sigma_{\varepsilon}{ }^{2}$, which represents the unexplained variance of the residual term associated with each equation in the VAR system or alternatively the variance of the unexpected asset returns. $R^{2}$ represents the variation in total asset returns, which is accounted for by the $\operatorname{VAR}(n)$ process where $n$ is the number of lags.

Given that the variance of unexpected returns accounts for most of the variance in total returns, we further decomposed the unexplained variance of the residual term (unexpected asset returns) associated with each equation in the VAR system denoted $\boldsymbol{\sigma}_{\boldsymbol{h}}^{2}$ into three components - cash-flow risk $\left[\operatorname{Var}\left(\boldsymbol{\eta}_{\boldsymbol{d}}\right)\right]$, discount-rate risk $\left[\operatorname{Var}\left(\boldsymbol{\eta}_{\boldsymbol{h}}\right)\right]$, and the covariance between future cash flows and discount rates $\left[\operatorname{Cov}\left(\boldsymbol{\eta}_{\boldsymbol{d}}\right),\left(\boldsymbol{\eta}_{\boldsymbol{h}}\right)\right]$-and report the results of this decomposition in table 5. For easier interpretation, the three terms $\operatorname{Var}\left(\boldsymbol{\eta}_{\boldsymbol{d}}\right), \operatorname{Var}\left(\boldsymbol{\eta}_{\boldsymbol{h}}\right)$, and $-\mathbf{2} \operatorname{Cov}\left(\boldsymbol{\eta}_{\boldsymbol{d}}\right),\left(\boldsymbol{\eta}_{\boldsymbol{h}}\right)$ are given as ratios to the variance of the unexpected real asset returns so that they sum to one. From table 5 , one can observe that a much larger portion of the variance in unexpected returns is explained by cash flow risk for real estate compared to either value-weighted stocks or small cap stocks from a relative standpoint. More specifically, cash-flow risk accounts for $79.8 \%$ (91.1\%) of the total variance of unexpected returns in a VAR(2) (VAR(3) model for equity REITs. ${ }^{12}$ This result is not unexpected since dividends are a significant component of REIT returns because REITs are required to pay out $95 \%$ of their earnings. In contrast, the contribution of cash-flow risk in accounting for the variance of unexpected returns in small stocks (30-33\%) and valueweighted stocks (33-38\%) is smaller. Discount-rate risk affects the unexplained variance of small cap stocks returns to a greater extent (79-95\%) than for equity REITs (38-47\%) and value-weighted stocks (33-36\%). In summary, the three risk components are roughly equal in accounting for unexplained variance of value-weighted stock returns, while cash-flow risk accounts for the major portion of the unexplained variation in equity REIT returns. Discount-rate risk accounts for most of the unexplained variation in small stock returns. However, the fact that cash-flow risk is the dominant risk attribute for the variation in unexpected equity REIT returns should not be interpreted to mean that changes in the expected future discount rate are unimportant, since discount rate risk comprises between $38 \%$ and

\footnotetext{
${ }^{12}$ Changes in future expected cash flows for equity REITs could arise in part from changing expectations in future rental rates, anticipated vacancies, and tentative absorption rates.
} 
$47 \%$ of the total unexpected real estate risk. ${ }^{13}$ The point is that both cash-flow risk and discount-rate risk are important components of real-estate risk even though the former accounts for twice as much variation in the unexpected return as the latter.

Table 5. Decomposition of the variance of unexpected real asset returns (standard errors are in parentheses).

\begin{tabular}{lccccc}
\hline Var Specification & $\sigma_{\epsilon}^{2}$ & $\operatorname{Var}\left(\eta_{\mathrm{d}}\right)$ & $\operatorname{Var}\left(\eta_{\mathrm{h}}\right)$ & $-2 \operatorname{Cov}\left(\eta_{\mathrm{d}}, \eta_{\mathrm{h}}\right)$ & $\operatorname{Corr}\left(\eta_{\mathrm{d}}, \eta_{\mathrm{h}}\right)$ \\
\hline $\begin{array}{l}\text { 2 Lags, Monthly } \\
\text { VWStk }\end{array}$ & 21.97 & 0.381 & 0.333 & 0.286 & -0.401 \\
& & $(0.21)$ & $(0.20)$ & $(0.19)$ & $(0.38)$ \\
EREIT & 22.67 & 0.798 & 0.467 & -0.265 & 0.217 \\
& & $(0.40)$ & $(0.40)$ & $(0.66)$ & $(0.41)$ \\
SmStk & 41.41 & 0.297 & 0.947 & -0.244 & 0.230 \\
& & $(0.13)$ & $(0.52)$ & $(0.61)$ & $(0.47)$ \\
3 Lags, Monthly & & & & & \\
VWStk & 21.15 & 0.327 & 0.359 & 0.315 & -0.460 \\
& & $(0.18)$ & $(0.17)$ & $(0.19)$ & $(0.40)$ \\
EREIT & 21.62 & 0.911 & 0.376 & -0.287 & 0.245 \\
& & $(0.57)$ & $(0.37)$ & $(0.83)$ & $(0.54)$ \\
SmStk & 39.98 & 0.329 & 0.794 & -0.123 & 0.120 \\
& & $(0.16)$ & $(0.39)$ & $(0.48)$ & $(0.42)$ \\
\hline
\end{tabular}

Notes: $\sigma_{\varepsilon}^{2}$ represents the unexplained variance of the residual term associated with each equation in the VAR system. $\eta_{\mathrm{d}}$ and $\eta_{\mathrm{h}}$ represent news about future cash flows and news about future expected returns respectively. They are calculated from the VAR system using equations 5 and 6 . The three terms $\operatorname{Var}\left(\eta_{d}\right), \operatorname{Var}\left(\eta_{h}\right)$, and $-2 \operatorname{Cov}\left(\eta_{d}, \eta_{h}\right)$ are given as ratios to the variance of the unexpected asset return so from 2 they sum to one.

From an absolute perspective, the difference in cash-flow risk between small stocks and EREITs decreases because the total variation in unexpected returns on small stocks is twice as large as that of EREITs. However, the cash-flow risk associated with EREITs is still larger than that for small stocks in accounting for 18.09 (.798*22.67) of the variance of unexpected EREIT returns in contrast to 12.30 $(41.41 * .297)$ of the variance of unexpected returns on small cap stocks in a VAR(2) model. This implies that cash-flow risk is approximately one and a half times $(18.09 \div 12.30)$ more important for equity REITs than for small cap stocks in accounting for the applicable variance of unexpected asset returns. Table 5 also reveals that cash-flow risk is positively correlated with discount-rate risk for equity REITs and small stocks. This means that whenever there is good news about future cash flow in real estate and small stocks, the investor will tend to become apprehensive about the future and thus demand higher expected future returns. This phenomenon tends to dampen the shock of cash-flow news and discountrate news to the market because the two work in opposite directions. News about future cash flow is good for the current asset price, while news about future expected return is bad for the current asset price.

\footnotetext{
${ }^{13}$ The reason that the sum of cash-flow risk and discount-rate risk exceeds $100 \%$ of total unexpected real-estate risk is that the covariance risk accounts for $-27 \%$ to $-28 \%$ of the total risk. We should also note that the standard errors in table 5 are overstated due to insufficient time series data, which in turn leads to understated T statistics. This is the reason for our claim that discount-rate risk is also an important component of total unexpected realestate risk.
} 


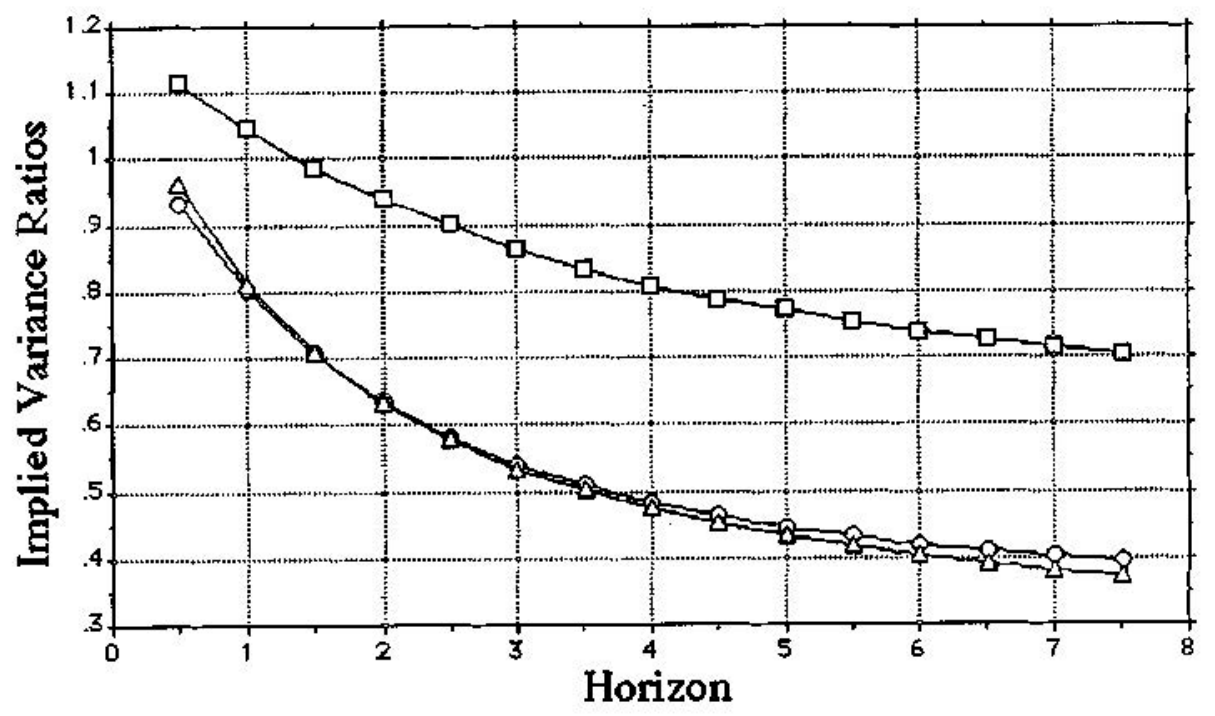

OVWStk DER+tit $\Delta$ Smstk

Figure 2. Implied variance ratios for a VAR(2) process.

Figure 2 provides a plot of the variance ratio calculations for EREITs, the value-weighted market index, and a small stock index. The variance ratios are calculated using six month intervals and go from six to ninety months. Figure 2 reveals that the general pattern for both value-weighted and small stocks are similar while the variance ratios for equity REITs are always larger than either of these stocks. For all three assets, the variance ratios peak at six months and then decline steadily. The ratio for REITs is greater than one for the six-month and twelve-month horizon, implying that the autocorrelations for holding period returns less than six months and one year are predominantly positive. For holding period returns of greater than one year, the variance ratio becomes smaller than one, implying that negative autocorrelations dominate for holding period returns that are longer than a year. This suggests that mean reversion also exists in EREIT returns. This mean reversion is consistent with the work by Liu and Mei (1991) that returns on EREITs are predictable. However, mean reversion is much weaker for equity REITs relative to value-weighted and small cap stocks, which have much smaller variance ratios and thus have a stronger negative autocorrelation in their returns. The reason that mean reversion is less important for EREITs is that EREIT returns are mainly driven by news about future cash flows and are much less influenced by news on future expected returns. The latter type of news is more likely to be affected by market overreaction or the changing perception of risk by investors.

\section{Summary and Conclusions}

Concerns over the nature of real-estate risk have tempered institutional investors participation in real estate. While several studies have addressed the smoothing aspects of risk measurement, this study provides another perspective on the nature of real-estate risk by decomposing real-estate risk using the present-value model of Campbell $(1987,1991)$, which allows the discount rate to vary through time in conjunction with a vector autoregressive process. Total real-estate risk is first decomposed into the variance of contemporaneous expected asset returns and the variance of unexpected asset returns. 
From this partitioning, the variance of unexpected returns is found to account for most of the variance in total returns regardless of the asset class. Given this result, the unexplained variance of asset returns is further decomposed into three components: cash-flow risk, discount-rate risk, and the covariation between cash-flow risk and discount-rate risk. The most interesting result from this decomposition is that cash-flow risk accounts for twice as much of the variance in unexpected real-estate returns as discount-rate risk although the latter is also an important risk component. In contrast, discount-rate risk accounts for most of the unexplained variation in small stock returns, while the three risk components are of equal importance in accounting for the unexplained variance of value-weighted stock returns. Another important contribution of the study is the finding that mean reversion is much weaker for equity REITs relative to value-weighted and small stocks, which suggests that a relatively longer holding period is required for real estate if a contrarian investment strategy is followed.

\section{Acknowledgments}

We wish to thank John Campbell for letting us use his variance decomposition algorithm and Doug Herald and Wayne Ferson for providing data on real-estate cap rates and business condition factors, respectively.

\section{Appendix: The Dividend-Ratio Model}

Campbell and Shiller (1988a) use a first-order Taylor series approximation of the log of the holding period return equation, $\boldsymbol{h}_{t+1}=\log \left(\left(\boldsymbol{P}_{t+1}+D_{t+1}\right) \div \boldsymbol{P}_{t}\right)$ to obtain the following equation:

$$
h_{t+1} \approx k+\delta_{t}-\rho \delta_{t+1}+\Delta d_{t+1}
$$

where $\boldsymbol{h}_{t+1}$ is the asset return in period $t+1, \boldsymbol{d}_{t}$ is the log of the real dividend paid during period $t, \boldsymbol{\delta}_{\boldsymbol{t}}$ is the log dividend-price ratio $\boldsymbol{d}_{\boldsymbol{t}+\mathbf{1}}-\boldsymbol{p}_{\boldsymbol{t}}, \boldsymbol{p}_{\boldsymbol{t}}$ is the log real stock price at the end of period $\mathrm{t}, \boldsymbol{\rho}$ is the average ratio of the stock price to the sum of the stock price and the dividend, and the constant $k$ is a nonlinear function of $\boldsymbol{\rho} .{ }^{14}$ The log dividend-price ratio model $\boldsymbol{\delta}$ is the next derived from equation A1 by treating equation $A 1$ as a difference equation relating $\delta_{t}$ to $\delta_{t+1}, \Delta d_{t+1}$ and $\boldsymbol{h}_{t+1}$, solving this equation forward, and imposing the terminal condition that $\boldsymbol{\delta}_{t+j}$ does not explode as i increases, e.g., $\lim _{j \rightarrow \infty} \boldsymbol{\rho}^{i}$ $\boldsymbol{\delta}_{\boldsymbol{t}+\mathbf{1}}=\mathbf{0}$ The resulting equation is

$$
\boldsymbol{\delta}_{\boldsymbol{t}}=\sum_{j=0}^{\infty} \rho^{j}\left(\boldsymbol{h}_{t+1+j}-\Delta \boldsymbol{d}_{t+j+j}\right)-\frac{\boldsymbol{k}}{\mathbf{1}-\boldsymbol{\rho}}
$$

\footnotetext{
${ }^{14}$ The equations used in this study differ slightly from those used in Campbell and Shiller (1988a, b) due to a difference in timing conventions. More specifically, we assume that the stock price at time $t$ and the conditional expectation of future variables are measured at the end of period $t$ rather than at the beginning of period $t$.
} 
This log dividend-price equation $\boldsymbol{\delta}_{\boldsymbol{t}}$ represents the present value of all future returns $\boldsymbol{h}_{t+j}$ and dividend growth rates $\Delta \boldsymbol{d}_{\boldsymbol{t}+\boldsymbol{j}}$, discounted at the constant rate $\boldsymbol{\rho}$ with a constant $\boldsymbol{k} /(\mathbf{1}-\boldsymbol{\rho})$ subtracted from this result. Equation A2 implies that if the dividend yield is currently large, high future returns will occur unless dividend growth is low in the future. Although all of the variables in (A2) are measured ex post, (A2) also holds ex ante. Consequently, equation 1 in the paper obtains if we use the ex ante version of equation A2 to substitute $\boldsymbol{\delta}_{\boldsymbol{t}}$ and $\boldsymbol{\delta}_{\boldsymbol{t}+\mathbf{1}}$ out of (A1). The reason for this is that $\boldsymbol{\delta}_{\boldsymbol{t}}$ is unchanged on the lefthand side of equation $A 2$ if we take expectations of equation $A 2$, conditional on information available at the end of time period $\boldsymbol{t}$, because $\boldsymbol{\delta}_{\boldsymbol{t}}$ is in the information set, and the righthand side becomes an expected discounted value. ${ }^{15}$

\section{References}

Campbell, John Y. "Stock Returns and the Term Structure." Journal of Financial Economics 18 (1987), 373-399.

Campbell, John Y. "A Variance Decomposition of Stock Returns, the H.G. Johnson Lecture to the Royal Economic Society." Economic Journal 101 (1991), 157-179.

Campbell, John Y, and John Ammer. "What Moves the Stock and Bond Markets? A Variance Decomposition for Long-Term Asset Returns." NBER Working Paper No. 3760, June 1991.

Campbell, John Y., and Jianping Mei. "Where Do Betas Come From? Asset Price Dynamics and the Sources of Systematic Risk." Working Paper, (1991) Princeton University.

Campbell, John Y, and Robert J. Shiller. "Cointegration and Tests of Present Value Models." Journal of Political Economy 95 (1987) 1062-1088.

Campbell, John Y., and Robert J. Shiller. "The Dividend-Price Ratio and Expectations of Future Dividends and Discount Factors." Review of Financial Studies 1 (1988a), 195-228.

Campbell, John Y, and Robert J. Shiller. "Stock Prices, Earnings, and Expected Dividends." Journal of Finance 43 (1988b), 661-676.

Chan, K.C., Patric Hendershott, and Anthony Sanders. "Risk and Return on Real Estate: Evidence from Equity REITs." AREUEA Journal 18 (1990), 431-452.

Chen, Nai-fu, Richard Roll, and Stephen Ross. "Economic Forces and the Stock Market." Journal of Business 59 (1986), 386-403.

Chow, Gregory C. Econometrics, New York: McGraw-Hill, 1983.

\footnotetext{
${ }^{15}$ See Campbell and Shiller (1988a) for an evaluation of the quality of the linear approximation in equations Al and A2.
} 
Fama, E., and K. French. "Permanent and Temporary Components of Stock Prices." Journal of Political Economy 96 (1988a), 246-273.

Fama, E., and K. French. "Dividend Yields and Expected Stock Returns." Journal of Financial Economics 22 (1988b), 3-25.

Fama, E., and K. French. "Business Conditions and Expected Return on Stocks and Bonds." Journal of Financial Economics 25 (1989), 23-49.

Person, W., and C. Harvey. "The Variation of Economic Risk Premiums." Journal of Political Economy, Forthcoming (1990).

Geltner, David. "Return Risk and Cash Flow Risk with Long-Term Riskless Leases in Commercial Real Estate." AREUEA Journal 18 (1990), 377-402.

Geltner, David. "Estimating Real Estate's Systematic Risk from Aggregate Level Appraisal-Based Returns." AREUEA Journal 17 (1989), 463-481.

Gibbons, Michael R., and Wayne Ferson. "Testing Asset Pricing Models with Changing Expectations and an Unobservable Market Portfolio." Journal of Financial Economics 14 (1985), 217-236.

Gyourko, Joseph, and Donald Keim, "What Does the Stock Market Tell Us About Real Estate Returns? Working Paper, The Wharton School, 1991.

Harvey, Andrew. The Econometric Analysis of Time Series, Cambridge: MIT Press, 1980.

Liu, Crocker H., and Jianping Mei. "The Predictability of Returns on Equity REITS and Their Co-Movement with Other Assets." Forthcoming in the Journal of Real Estate Finance and Economics, 1991.

Lo, Andrew W, and A. Craig MacKinlay. "Stock Market Prices Do Not Follow Random Walks: Evidence from a Simple Specification Test." Review of Financial Studies 1 (1988), 41-66.

Mei, Jianping, and Anthony Saunders. "Bank Risk and Real Estate: An Asset Pricing Perspective." Working Paper, New York University, 1991.

Richardson, Matthew, and James H. Stock. "Drawing Inferences from Statistics Based on Multiyear Asset Returns." Journal of Financial Economics 25 (1989), 323-348.

Roll, Richard, and Stephen A. Ross. "An Empirical Investigation of the Arbitrage Pricing Theory." Journal of Finance 35 (1980), 1073-1103.

Ross, Stephen A., and Randall Zisler. "Managing Real Estate Portfolios, Part 3: A Close Look at Equity Real Estate Risk." Real Estate Research. Goldman Sachs, November 1987.

Titman, Sheridan, and Arthur Warga. "Risk and the Performance of Real Estate Investment Trusts: A Multiple Index Approach." AREUEA Journal 14 (1986), 414-431. 
White, Halbert. "A Heteroskedasticity-Consistent Covariance Matrix Estimator and a Direct Test for Heteroskedasticity." Econometrica 48 (1980), 817-838. 